\title{
フライアッシュセメントB種を STUDY ON CARBONATION RATE 使用したコンクリートの屋外暴 COEFFICIENTS OF CONCRETE 露中性化速度係数に関する研究 USING FLY ASH CEMENT (TYPE-B) IN OUTDOOR EXPOSURE TEST
}

船本憲治— * 1

キーワード :

フライアッシュセメント B 種, 中性化, 中性化速度係数, 中性化速度係数比, 屋外暴露試験

Keywords:

Fly ash cement (type-B), Carbonation, Carbonation rate coefficient, Carbonation rate coefficient ratio, Outdoor exposure test

\section{Kenji FUNAMOTO $\_* 1$}

This paper describes the results of research study on carbonation rate coefficients of concrete using fly ash cement (type-B) in outdoor exposure test continued more than five years. As the result, the main conclusions are as follows. 1) The carbonation rate coefficients of concrete using fly ash cement can be expressed by the water-cement ratio. 2) The water-binder ratio has a good association with carbonation rate coefficient ratio. 3) The cement factor $\left(\alpha_{2}\right)$ of the AIJ durability design recommendation can be calculated with 1.1 and the water-binder ratio factor $\left(\alpha_{3}\right)$ can be calculated with $(\mathrm{W} /(\mathrm{C}+\mathrm{F})-0.304)$.

\section{1.はじめに}

フライアッシュ（以下，FA）をセメント内割で使用したコンクリ ートは, 初期強度が小さく, セメントの水和により生成した $\mathrm{Ca}(\mathrm{OH})_{2}$ がポゾラン反応によって消費されるため, 一般のコンクリートに比 べて中性化速度が速くなる。しかし, 初期段階において十分な養生 を行えば，長期的にはコンクリート中で緻密な硬化体組織が形成さ れ，中性化が抑制されることが期待される。

そのような中, FA コンクリートの中性化の性状は, 促進試験では 多くの知見が得られているが，それはそのまま実構造物の性状を表 しているとは言い難く, 暴露試験の成果の反映が求められている。 そこで，本論文では，FA セメントB 種を使用したコンクリート に関して，屋外暴露した既往文献を調查し，長期に亘る中性化特性 を検討した。さらに，この結果を基に，日本建築学会（以下，AIJ) 「鉄筋コンクリート造建築物の耐久設計施工指針（案）・同解説 (2004)（以下, RC 建築物耐久設計施工指針)」で示されている中性 化速度式の諸係数について一つの提案を行った。なお, 今回の検討 では，普通ポルトランドセメントに FA を $20 \%$ 置換した結合材を対 象とした文献もあり，それも FA セメント B 種に含めた。

\section{FA コンクリートの中性化特性および耐久設計基準強度に関する AIJ 指針等の記述}

「建築工事標準仕様書・同解説（JASS5）（2009）」では，「促進中 性化試験では, セメントの種類に関係なく試験開始時の圧縮強度の 逆数と中性化速度とは直線関係にあり, 圧縮強度を指標に中性化速 度が評価できる」, 「屋外暴露試験では, 強度が同じであれば同程度 の中性化速度係数となる結果が得られる」となっている。

「FA を使用するコンクリートの調合設計・施工指針・同解説 (2007)」では，「屋外暴露中性化試験の結果より，FA II 種で FA の 置換率が $20 \%$ 以下の場合は耐久設計基準強度の割増しは必要ない が, 置換率が 30\%を超える場合は一般のコンクリートに比べておよ
そ $3 \mathrm{~N} / \mathrm{mm}^{2}$ の強度割増しが必要になる」となっている。

「高流動コンクリートの材料・調合・製造・施工指針（案）・同解 説(1997)」では，促進中性化試験の結果より，「中性化速度係数は水 セメント比との間に直線関係が認められ, 結合材として用いた FA は中性化抵抗性にほとんど関与しない」となっている。

$\lceil\mathrm{RC}$ 建築物耐久設計施工指針」では，中性化速度係数 $\mathrm{A}$ の評価 式が下式(1)のように示されている。

$$
\begin{aligned}
& \mathrm{A}=\mathrm{k} \cdot \alpha_{1} \cdot \alpha_{2} \cdot \alpha_{3} \cdot \beta_{1} \cdot \beta_{2} \cdot \beta_{3} \cdots \cdots \cdots \cdots \cdots \cdots(1) \\
& \mathrm{k} \text { : 定数 }(\mathrm{mm} / \sqrt{ } \text { 年 }) \\
& \alpha_{1} \text { : 骨材種類による係数 } \beta_{1} \text { : 温度による係数 } \\
& \alpha_{2} \text { : セx慟類による係数 } \beta_{2} \text { : 湿度による係数 } \\
& \alpha_{3} \text { : 水セx䚹による係数 } \beta_{3}: \mathrm{CO}_{2} \text { 濃度による係数 }
\end{aligned}
$$

上式(1)において, 普通ポルトランドセメントを使用したコンクリ 一トの場合は, $\alpha_{2}=1, \alpha_{3}=\mathrm{W} / \mathrm{C}-0.38$ であり, 中性化は W/C が $38 \%$ 以下ではゼロであるとの考えが反映されている。一方, FA セメント $\mathrm{B}$ 種の場合は， $\alpha_{2}=1.8$ が推奨されているが， $\alpha_{3}$ はセメントの種類 に関係なく $\mathrm{W} / \mathrm{C}-0.38$ が適用できると考えられているように読める。

\section{3. 既往文献における屋外暴露中性化試験の概要}

今回, 実構造物の長期的な中性化性状を評価する目的で, FA セメ ントB 種および普通ポルトランドセメントに対し FA を $20 \%$ 置換し た結合材（FA セメント B 種相当）を使用したコンクリートを，5年 以上屋外暴露した既往文献 1) 5)を調查し, その結果を表ー 1 に示す。 なお, 選定文献は, FA の有無による中性化速度比を求める必要があ り, 水結合材比一定でFAの有無のデータが得られている文献とし, FA セメント B 種の FA 置換率は平均的な $18 \%$ と仮定した。また, FA 種別は, 1999 年以降は FA II 種であるが, それ以前は JIS 改定前 の FA であり FA II 種相当品である。

文献 1)は，普通ポルトランドセメントおよび FA セメント B 種を 使用した調合で，前水中養生期間を 3〜28 日とし， $\phi 15 \times 30 \mathrm{~cm}$ 供試 
表 1 屋外暴露中性化試験の条件および結果並びに中性化速度比の推定

\begin{tabular}{|c|c|c|c|c|c|c|c|c|c|c|c|c|c|c|c|c|c|c|c|}
\hline \multirow[b]{2}{*}{$\begin{array}{l}\text { 文 } \\
\text { 献 }\end{array}$} & \multirow[b]{2}{*}{ 試験体 } & \multirow[b]{2}{*}{\begin{tabular}{|l} 
試験 \\
機関
\end{tabular}} & \multirow[b]{2}{*}{$\begin{array}{l}\text { 暴露 } \\
\text { 汱況 }\end{array}$} & \multirow[b]{2}{*}{$\begin{array}{l}\text { スララ } \\
(\mathrm{cm})\end{array}$} & \multirow[b]{2}{*}{$\begin{array}{c}\text { 空気 } \\
\text { 量 } \\
(\%)\end{array}$} & \multirow[b]{2}{*}{\begin{tabular}{|c|} 
混和 \\
剤
\end{tabular}} & \multirow[b]{2}{*}{$\begin{array}{c}\text { 前 } \\
\text { 養生 }\end{array}$} & \multicolumn{3}{|c|}{ 単位量 $\left(\mathrm{kg} / \mathrm{m}^{3}\right)$} & \multirow[b]{2}{*}{$\begin{array}{c}\mathrm{F} / \\
(\mathrm{C}+\mathrm{F}) \\
(\%)\end{array}$} & \multirow[b]{2}{*}{$\begin{array}{c}\text { W/ } \\
(\mathrm{C}+\mathrm{F}) \\
(\%)\end{array}$} & \multirow[b]{2}{*}{$\begin{array}{l}\text { W/C } \\
(\%)\end{array}$} & \multicolumn{4}{|c|}{ 試験結果 } & \multirow[b]{2}{*}{$\begin{array}{c}\text { 逆算した } \\
\text { FAセx゙ } \\
\text { B種の } \\
\alpha_{2}{ }^{*}\end{array}$} & \multirow[b]{2}{*}{$\begin{array}{l}\text { 推定 } \\
\text { 值 } \\
\gamma^{*}\end{array}$} \\
\hline & & & & & & & & W & $\mathrm{C}$ & $\mathrm{F}$ & & & & $\begin{array}{l}\text { 材䶡 } \\
\text { (年) }\end{array}$ & $\begin{array}{l}\text { 深さ } \\
(\mathrm{mm})\end{array}$ & $\begin{array}{c}\text { 中性化 } \\
\text { 速度係数 } \\
\mathrm{A} \\
(\mathrm{mm} / \sqrt{ } \text { 年 })\end{array}$ & $\begin{array}{c}\text { 中性化 } \\
\text { 速度係数比 } \\
\text { (FA有/無) } \\
\gamma\end{array}$ & & \\
\hline \multirow{6}{*}{ 1) } & \multirow{6}{*}{$\begin{array}{c}\phi 15 \times \\
30 \mathrm{~cm}\end{array}$} & \multirow{6}{*}{$\begin{array}{c}\text { 小野 } \\
\text { 田ゼ } \\
\text { 卜 }\end{array}$} & \multirow{6}{*}{ 屋外 } & \multirow{6}{*}{$\begin{array}{c}\text { 設定値 } \\
18\end{array}$} & \multirow{6}{*}{$\begin{array}{c}\text { 設定 } \\
\text { 値 } \\
4\end{array}$} & & 3日 & 180 & 327 & 0 & 0 & 55 & 55 & 5 & 2.3 & 1.03 & & & \\
\hline & & & & & & & 水中 & 180 & 267 & 60 & 18 & 55 & 67 & 5 & 3.3 & 1.48 & 1.43 & 0.99 & 1.59 \\
\hline & & & & & & AE減 & 7日 & 180 & 327 & 0 & 0 & 55 & 55 & 5 & 2.3 & 1.03 & & & \\
\hline & & & & & & 水剂 & 水中 & 180 & 267 & 60 & 18 & 55 & 67 & 5 & 4.0 & 1.79 & 1.74 & 1.20 & 1.59 \\
\hline & & & & & & & 28 日 & 180 & 327 & 0 & 0 & 55 & 55 & 5 & 0.5 & 0.22 & & - & - \\
\hline & & & & & & & 水中 & 180 & 267 & 60 & 18 & 55 & 67 & 5 & 2.0 & 0.89 & 4.00 & - & - \\
\hline & & & & 18.0 & 3.4 & & & 165 & 300 & 0 & 0 & 55 & 55 & 10 & 9.9 & 3.13 & & & \\
\hline 2) & $\phi 15 \times$ & 足利 & 层处 & 18.5 & 3.4 & F剂 & 7日 & 157 & 234 & 51 & 18 & 55 & 67 & 10 & 16.1 & 5.09 & 1.63 & 1.12 & 1.60 \\
\hline 2) & $30 \mathrm{~cm}$ & $\begin{array}{l}\text { 工寀 } \\
\text { 大学 }\end{array}$ & 厓外 & 17.5 & 3.5 & AE葪 & 水中 & 162 & 249 & 0 & 0 & 65 & 65 & 10 & 15.5 & 4.90 & & & \\
\hline & & & & 18.0 & 3.4 & & & 154 & 194 & 43 & 18 & 65 & 79 & 10 & 20.9 & 6.61 & 1.35 & 1.06 & 1.41 \\
\hline & & & & & 4.3 & & & 178 & 356 & 0 & 0 & 50 & 50 & 10 & 3.7 & 1.17 & & & \\
\hline & & 建設 & 屋外 & & 4.4 & & & 173 & 284 & 62 & 18 & 50 & 61 & 10 & 5.7 & 1.80 & 1.54 & 0.94 & 1.80 \\
\hline 2) & $15 \times 15$ & 省建 & (半 & 設定伹 & 4.3 & AE減 & 28日 & 176 & 293 & 0 & 0 & 60 & 60 & 10 & 7.8 & 2.47 & & & \\
\hline 3) & $\times 50 \mathrm{~cm}$ & 築研 & $\begin{array}{l}\text { 分に } \\
\text { 屋 }\end{array}$ & 18 & 5.0 & 水剂 & 水中 & 171 & 234 & 51 & 18 & 60 & 73 & 10 & 9.9 & 3.13 & 1.27 & 0.95 & 1. 48 \\
\hline & & 究所 & $\begin{array}{l}\text { 珢 } \\
\text { 根) }\end{array}$ & & 4.6 & & & 176 & 251 & 0 & 0 & 70 & 70 & 10 & 11.2 & 3.54 & & & \\
\hline & & & & & 4.0 & & & 171 & 200 & 44 & 18 & 70 & 86 & 10 & 14.4 & 4.55 & 1.29 & 1.04 & 1.36 \\
\hline & & & & 19.0 & 4.2 & & & 180 & 450 & 0 & 0 & 40 & 40 & 9 & - & 0.70 & & & - \\
\hline & & & & 19.5 & 4.5 & & 5 日 & 175 & 350 & 88 & 20 & 40 & 50 & 9 & - & 1.25 & 1.79 & 0.37 & - \\
\hline & & & & 20.0 & 4.0 & & 封縅 & 180 & 300 & 0 & 0 & 60 & 60 & 9 & - & 2.60 & & & \\
\hline & & & & 19.5 & 4.6 & & & 175 & 234 & 58 & 20 & 60 & 75 & 9 & - & 4.00 & 1.54 & 1.15 & 1.48 \\
\hline & & 九州 & & 19.0 & 4.2 & & & 180 & 450 & 0 & 0 & 40 & 40 & 9 & - & 0.00 & - & - & - \\
\hline & $10 \times 10$ & 電力 & & 19.5 & 4.5 & AE減 & 7日 & 175 & 350 & 88 & 20 & 40 & 50 & 9 & - & 1.30 & - & - & - \\
\hline 4) & $\times 40 \mathrm{~cm}$ & 九州 & 厔外 & 20.0 & 4.0 & 水剂 & 封縅 & 180 & 300 & 0 & 0 & 60 & 60 & 9 & - & 2.25 & & & \\
\hline & & 大学 & & 19.5 & 4.6 & & & 175 & 234 & 58 & 20 & 60 & 75 & 9 & - & 3.50 & 1.56 & 1.16 & 1.48 \\
\hline & & & & 19.0 & 4.2 & & & 180 & 450 & 0 & 0 & 40 & 40 & 9 & - & 0.00 & - & _- & - \\
\hline & & & & 19.5 & 4.5 & & 10日 & 175 & 350 & 88 & 20 & 40 & 50 & 9 & - & 1.00 & - & - & - \\
\hline & & & & 20.0 & 4.0 & & 封縅 & 180 & 300 & 0 & 0 & 60 & 60 & 9 & - & 2.10 & & & \\
\hline & & & & 19.5 & 4.6 & & & 175 & 234 & 58 & 20 & 60 & 75 & 9 & - & 3.60 & 1.71 & 1.28 & 1.48 \\
\hline & & & & & & & & 169 & 423 & 0 & 0 & 40 & 40 & 7 & - & 0.40 & & & - \\
\hline & & 竹中 & & & & & & 169 & 338 & 85 & 20 & 40 & 50 & 7 & - & 0.87 & 2.18 & & - \\
\hline & $10 \times 10$ & \begin{tabular}{|l|} 
工務 \\
占 .
\end{tabular} & & 設定値 & 設定 & AE減 & 28日 & 160 & 320 & 0 & 0 & 50 & 50 & 7 & - & 0.90 & & & \\
\hline 5) & $\times 40 \mathrm{~cm}$ & 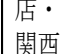 & 屋外 & 18 & $\begin{array}{c}\text { 值 } \\
4.5\end{array}$ & 水剂 & 水中 & 160 & 256 & 64 & 20 & 50 & 63 & 7 & - & 1.49 & 1.66 & 1.01 & 1.80 \\
\hline & & 電力 & & & & & & 162 & 270 & 0 & 0 & 60 & 60 & 7 & - & 1.40 & 15 & 111 & 148 \\
\hline & & & & & & & & 162 & 216 & 54 & 20 & 60 & 75 & 7 & - & 2.11 & 1.51 & 1.12 & 1.48 \\
\hline
\end{tabular}

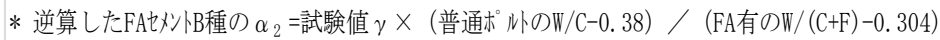

** $\alpha_{2}=1.1, \quad \alpha_{3}=\left(\mathrm{FA}\right.$ 有のW/(C+F) -0. 304) と仮定した時の推定值 $\gamma=\alpha_{2} \times \alpha_{3} /($ 普通术 WのW/C-0.38)

体を材齢 5 年まで屋外暴露した試験である。なお, 混和剤は $\mathrm{AE}$ 減 水剤を使用している。

文献 2)は，普通ポルトランドセメントおよび FA セメント B 種を 使用した調合で， $\phi 15 \times 30 \mathrm{~cm}$ 供試体を材齢 10 年まで屋外暴露した 試験である。なお，混和剤は $\mathrm{AE}$ 剂を使用し，前養生は，材齢 7 日 まで $20^{\circ} \mathrm{C}$ 水中養生とし, 材齢 28 日までは室温 $20^{\circ} \mathrm{C} \cdot$ 湿度 $80 \%$ とし, その後, 屋外暴露している。

文献 3)は，普通ポルトランドセメントおよび FA セメント B 種を 使用した調合で， $15 \times 15 \times 50 \mathrm{~cm}$ 供試体を材齢 10 年まで屋外暴露し た試験である。なお，混和剤は $\mathrm{AE}$ 減水剤を使用し，養生は，材齢 28 日まで $20^{\circ} \mathrm{C}$ 水中養生とし, その後, 架台上に暴露している。また,
この架台の半分には屋根がかかっており，この下の供試体は雨がか りが無い条件となっている。

文献 4)は, ベースセメントを普通ポルトランドセメントとし, FA 置換率を 0，20\%とした調合で，前封縅養生期間を 5〜10 日とし, $10 \times 10 \times 40 \mathrm{~cm}$ 供試体を材齢 9 年まで屋外暴露した試験である。なお, 混和剤は $\mathrm{AE}$ 減水剤を使用している。

文献 5)は，ベースセメントを普通ポルトランドセメントとし，FA 置換率を $0 ， 20 \%$ とした調合で，前水中養生期間は 28 日とし，10× $10 \times 40 \mathrm{~cm}$ 供試体を材齢 7 年まで屋外暴露した試験である。なお, 混 和剤は $\mathrm{AE}$ 減水剤を使用している。 


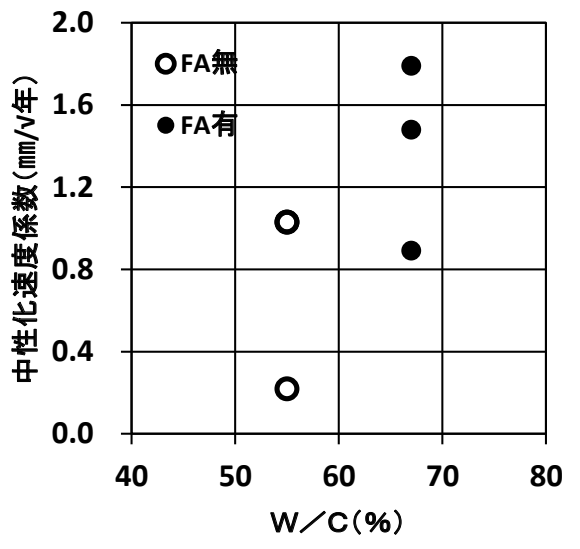

図 $1 \mathrm{~W} / \mathrm{C}$ と中性化速度係数の関係

(文献 1)【 $₫ \fallingdotseq F A 】$

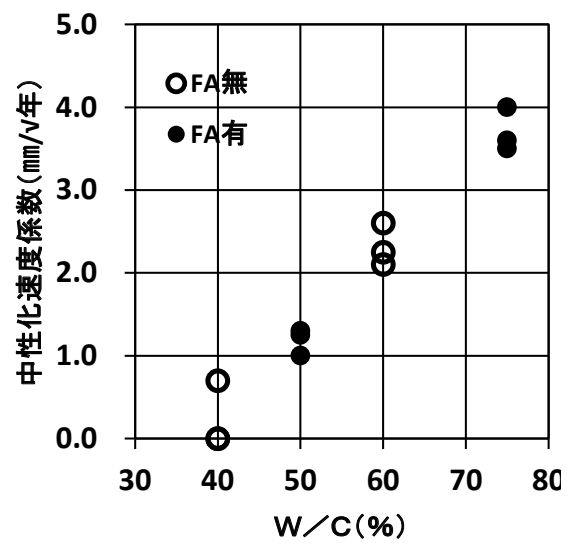

図 $4 \mathrm{~W} / \mathrm{C}$ と中性化速度係数の関係

(文献 4)【 $\mathrm{N} \fallingdotseq \mathrm{FA}$ 】

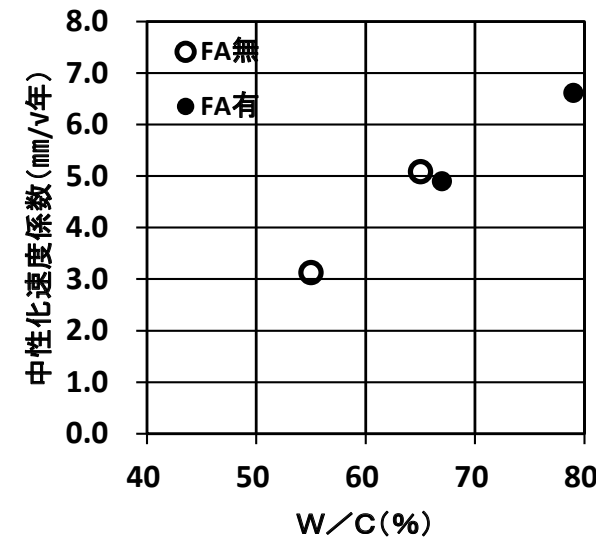

図 2 W/C と中性化速度係数の関係 (文献 2)【N>FA】

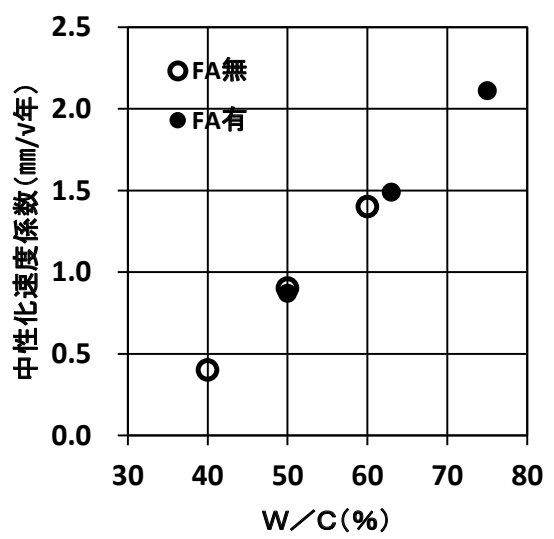

図 5 W/C と中性化速度係数の関係

(文献 5)【NうFA】

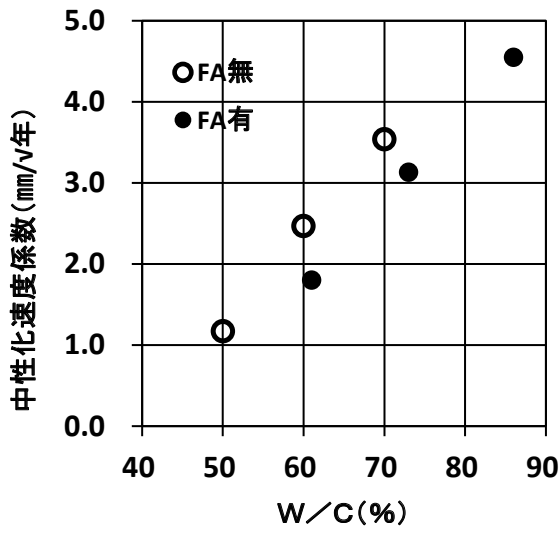

図 $3 \mathrm{~W} / \mathrm{C}$ と中性化速度係数の関係

(文献 3)【N>FA】

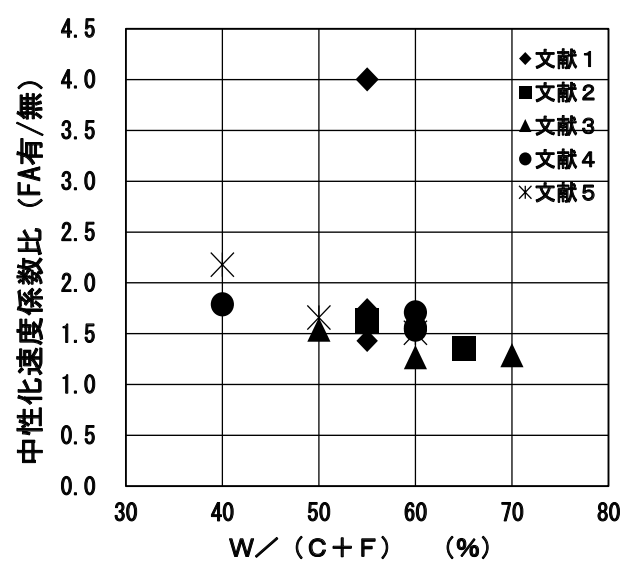

図 6 水結合材比 $(W /(C+F))$ と 中性化速度係数比（FA 有/無）の関係

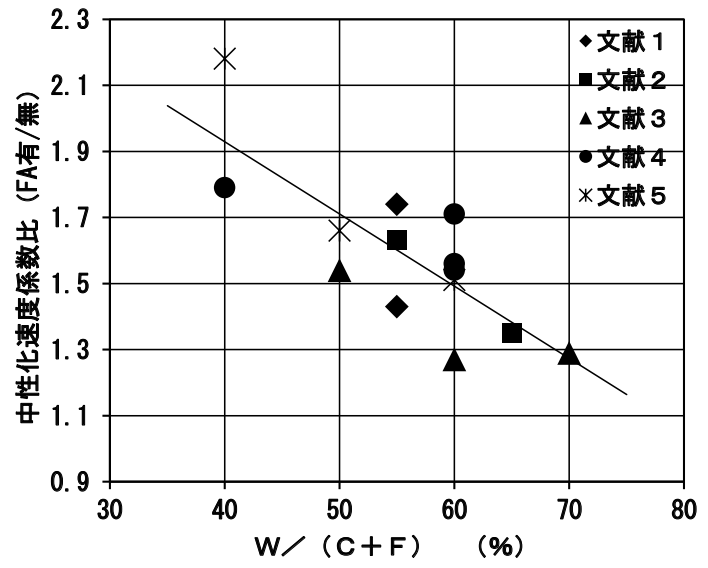

図 7 水結合材比 $(\mathrm{W} /(\mathrm{C}+\mathrm{F}))$ と 中性化速度係数比 (FA 有/無) の関係

4. 既往文献による屋外暴露中性化試験の結果

4.1 水ポルトランドセメント比 (W/C) との関係

今回対象とした文献の屋外暴露中性化試験結果を表一 1 に示す。

なお, 水セメント比 $40 \%$ で中性化速度係数がゼロとなっている場合 は中性化速度係数比（FA 有/無）の值が無限大となるので, 以降の 検討ではそのデータは削除した。

各文献における水ポルトランドセメント比（W/C）と中性化速度
係数の関係を図ー1〜 5に示す。なお, ここで, $\mathrm{N}$ は普通ポルトラン ドセメント, FA は FA セメント B 種である。

その結果, 各中性化速度係数は, 環境条件や養生等の影響により 各文献により異なっているが, 中性化速度係数をW/C で評価すると, FA の有無に関係なく良い相関が見られ，同一W/Cでは, FA コンク リートの方が同等かやや中性化が小さくなっている。また，多少の はらつきはあるものの, 中性化は, 前述の $\mathrm{AIJ} 「 \mathrm{RC}$ 建築物耐久設計 施工指針」の考えとも一致し $\mathrm{W} / \mathrm{C}=38 \%$ 近くでゼロになっている。

\section{2 FA の有無による中性化速度の影響}

今回対象とした文献の屋外暴露中性化試験による, FA の有無によ る中性化速度係数比 $(\gamma)$ の結果を表一 1 に示すとともに, 水結合 材比 $(\mathrm{W} /(\mathrm{C}+\mathrm{F}))$ との関係を図ー6および図ー7 に示寸。なお, 図一 6 では, 文献 1)において, 普通ポルトランドセメントの場合で前水 中養生 28 日の中性化深さの夕が他に比べて著しく小さく, その結果, 中性化速度係数比が一つだけ 4.0 と特に大きい值となっており, そ のことを考慮し図ー7 はその值を除いて再度相関を分析したもので ある。

図ー7 によると, 水結合材比と FA の有無による中性化速度係数比 に良い相関 ( $\mathrm{Y}=2.803-0.022 \mathrm{X}$, 相関係数 0.791) が見られ, 水結合材 比が大きくなるほど中性化速度係数比（FA 有/無）は小さくなって いる。 


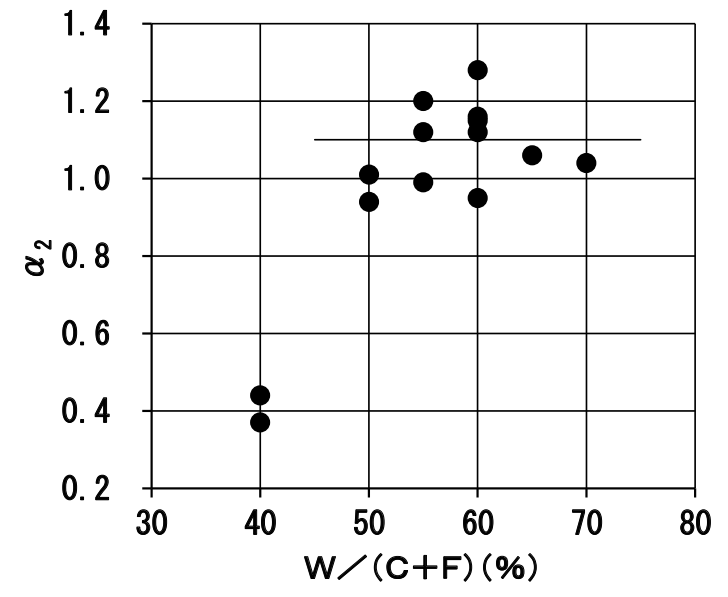

図 8 水結合材比 $(\mathrm{W} /(\mathrm{C}+\mathrm{F}))$ と $\alpha_{2}$ の関係

5. AIJ「RC 建築物耐久設計施工指針」における中性化速度係数に 関する考察

FA セメント B 種の場合は， $\alpha_{2}=1.8$ が推奨されているが， $\alpha_{3}$ は セメントの種類に関係なく $\mathrm{W} / \mathrm{C}-0.38$ が適用できると考えられてい るように読め, 今回, 考察を行った。

FA セメント B 種の場合は, 前述の図ー1 5 のように, 中性化深 さを水ポルトランドセメント比 (W/C) で評価すると FA の有無に 関係なく良い相関が見られ，多少のばらつきはあるものの，中性化 は W/C=38\%近くでゼロになっている。

従って, FA を $20 \%$ 置換している FA コンクリートの $\mathrm{W} / \mathrm{C}=0.38$ は $\mathrm{W} /(\mathrm{C}+\mathrm{F})$ では 0.304 に相当しており, FA セメント $\mathrm{B}$ 種では $\alpha_{3}=$ $\mathrm{W} /(\mathrm{C}+\mathrm{F})-0.304$ となり, 中性化は $\mathrm{W} /(\mathrm{C}+\mathrm{F})$ が 30.4\%以下ではゼロで あると考えるのが適当と推察される。

その考えのもと, 文献 1)〜 5)の試験值から逆算した FA セメント B 種の $\alpha_{2}$ を表 -1 に, 水結合材比 $(\mathrm{W} /(\mathrm{C}+\mathrm{F}))$ との関係を図-8 に示 す。その中で, FA セメント B 種の水結合材比 $40 \%$ では, 比較した 普通ポルトランドセメントの水セメント比が $40 \%$ と中性化ゼロの $38 \%$ に近く中性化が僅かでありその中性化速度比の影響が大きく現 れ易いことによるものか， $\alpha_{2}$ が著しく小さな值になっている。しか し, 水結合材比 $50 \sim 70 \%$ ではほぼ $\alpha_{2}=1.1$ が採用できると思われる。

その結果, FA セメント B 種において, 中性化速度係数算出に対 し, $\alpha_{2}=1.1, \quad \alpha_{3}=\mathrm{W} /(\mathrm{C}+\mathrm{F})-0.304$ が提案できそうである。なお, ここで $\alpha_{2}$ が FA 置換率 18〜20\%による混合比 $((\mathrm{C}+\mathrm{F}) / \mathrm{C})$ の 1.22 1.25 より小さい值となっているのは, 同一 $\mathrm{W} / \mathrm{C}$ では FA コンクリー 卜の方が中性化が同等かやや小さくなっており, FA が多少中性化に 寄与していることによるものではないかと考えられる。

上記を検証するために，文献 1)～5)の試験において，推定式によ る中性化速度係数比（FA 有/無）と試験值による中性化速度係数比 (FA 有/無) の関係を図ー9に示す。なお，ここで，推定式による中 性化速度係数比 (FA 有/無) $\gamma$ の算定は, 前述の(1)式において, $\alpha_{1}$, $\beta_{1}, \quad \beta_{2}, \quad \beta_{3}$ は FA の有無で同じとし， $\alpha_{2}$ および $\alpha_{3}$ が影響するも のとし， $\gamma=1.1 \times\{\mathrm{FA}$ 有の $\mathrm{W} /(\mathrm{C}+\mathrm{F})-0.304\} /\{1.0 \times$ (普通术忆の $\mathrm{W} / \mathrm{C}-0.38)$ \}とした。

図ー9によると，推定值と試験值は，ばらつきはあるもののほぼ 対応しており, FA セメント B 種の水結合材比 50〜 70\%の範囲にお

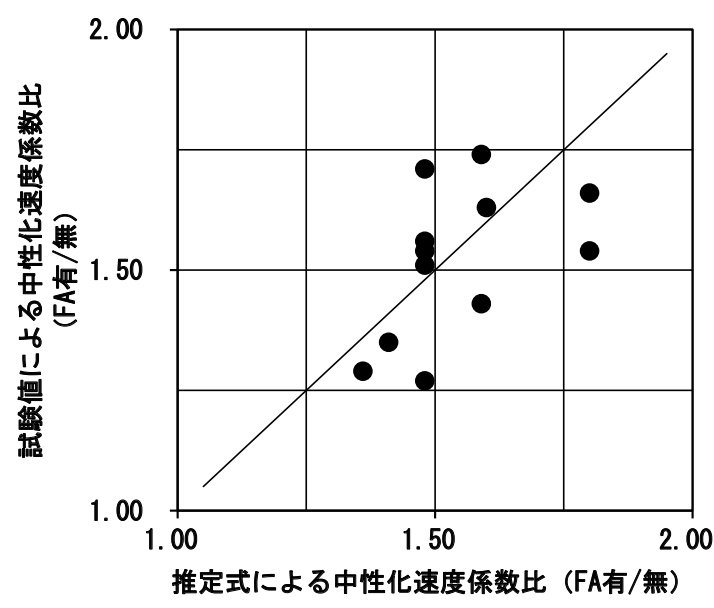

図 9 推定式による中性化速度係数比 (FA 有/無) と 試験值による中性化速度係数比（FA 有/無）の関係

いて, 中性化速度係数算出のための $\alpha_{2}=1.1, \quad \alpha_{3}=\mathrm{W} /(\mathrm{C}+\mathrm{F})-0.304$ の妥当性が確認できた。

\section{6. まとめ}

今回，FA セメント B 種を使用したコンクリートに関して，5 年以 上屋外暴露した既往文献を調查し, 長期に亘る中性化特性を検討し た。さらに，この結果を基に， AIJ $「 \mathrm{RC}$ 建築物耐久設計施工指針」 で示されている FA セメント B 種における中性化速度式の係数の検 討を行い, 以下の結果が得られた。

1) 中性化深さを水ポルトランドセメント比 (W/C) で評価すると, FA の有無に関係なく良い相関が見られ, 同一W/C では FA コ ンクリートの方が同等かやや中性化が小さくなる傾向となる。

2) 水結合材比 $(\mathrm{W} /(\mathrm{C}+\mathrm{F}))$ と $\mathrm{FA}$ の有無による中性化速度係数比に 良い相関が見られ, 水結合材比が大きくなるほど中性化速度比 (FA 有/無）は小さくなる。

3) 水結合材比 $(\mathrm{W} /(\mathrm{C}+\mathrm{F})) 50 \sim 70 \%$ の範囲において, 中性化速度係 数算出に関して $\alpha_{2}=1.1 ， \quad \alpha_{3}=\mathrm{W} /(\mathrm{C}+\mathrm{F})-0.304$ が有効である。

なお，今回は異なる環境条件や養生条件に対して中性化速度係数 比 (FA 有/無) を共通の指標として検討を行ったため, 水結合材比 $40 \%$ では十分な結果が得られず, 結果として得られた提案式は適用 範囲が狭くなっており, 今後, 同一の条件で $\alpha_{2}$ と $\alpha_{3}$ を同時に求め る等の検討も行い, 更に適用範囲の広い予測式を検討していきたい。

\section{参考文献}

1) 中村秀三ほか: 各種セメトを用いたコンクリートの屋外暴露永年材齢試験, セメント コンクリート論文集，No.48，pp.524-529，1994

2) 依田彰彦ほか：8 種類のセメンを用いた $\mathrm{AE}$ コンクリートの中性化速さについて, 第 52 回也x忮術大会講演要旨, pp.258-259, 1998

3) 長谷川拓哉ほか：中性化における環境条件を考慮した曝露試験と促進試 験の対応に関する検討, 第 52 回セx庪術大会講演要旨, pp.268-269, 1998

4) 船本憲治ほか：FA を使用したコンクリートの材齢 9 年における中性化曝露試験 報告（その 1：FA を内割混合したコンクリートの試験結果），AIJ 大会学術講演 梗概集（九州)，pp.373-374，2007.8

5)押田文雄ほか：中庸熱 FAセxンを使用したコンクリートの中性化速度係数, AIJ 技術報告集，Vol.20，No.45，pp.451-456，2014.6

[2014 年 10 月 14 日原稿受理 2015 年 2 月 16 日採用決定］ 